\title{
Selection of parents and segregating populations of common bean with high agronomic potential and slow seed-coat darkening ${ }^{1}$
}

\author{
Fernanda de Cássia Silva ${ }^{2}$, Helton Santos Pereira ${ }^{3}$, Patrícia Guimarães Santos Melo $^{2}$, Leonardo Cunha Melo ${ }^{3}$
}

\section{ABSTRACT}

Choosing parents and segregating populations are fundamental steps for the success in plant breeding. For the common bean crop, the development of genotypes that combine favorable agronomic traits and seed quality may increase the chances of adopting new cultivars. This study aimed to select promising parents and segregating populations to develop slow seed-coat darkening lines, together with high grain yield, lodging tolerance and short seed cooking time after storage, as well as to investigate the relationship between seed-coat darkening and seed cooking time after storage. Twenty segregating populations $\left(\mathrm{F}_{3}, \mathrm{~F}_{4}\right.$ and $\mathrm{F}_{5}$ generations) and their parents were evaluated. The sum of ranks index for combined traits was used in the selection of superior populations. Genetic and phenotypic correlations between seed-coat darkening and cooking time after storage were estimated. Among the parents, the BRSMG Madrepérola cultivar was the most promising to generate lines with seedcoat darkening. The superior populations were BRSMG Madrepérola x IPR Saracura, BRSMG Madrepérola x BRS Sublime, BRSMG Madrepérola x BRS Estilo and BRSMG Madrepérola x BRS Notável. A linear relationship was not found between seed-coat darkening and seed cooking time after storage, indicating that the first trait is not an adequate indicator to infer about seed cooking time.

KEYWORDS: Phaseolus vulgaris; seed quality; selection index.

\section{INTRODUCTION}

Common bean breeding programs in Brazil generally aim to develop cultivars that combine high grain yield and other favorable phenotypic traits of interest to farmers. An upright plant architecture and a greater lodging tolerance are currently among the phenotypes most in demand, because cultivars

\begin{abstract}
RESUMO
Seleção de genitores e populações segregantes de feijoeiro comum com alto potencial agronômico e escurecimento lento de grãos

A escolha de genitores e populações segregantes são etapas primordiais para o sucesso do melhoramento de plantas. Para a cultura do feijoeiro comum, o desenvolvimento de genótipos que associem caracteres agronômicos e de qualidade dos grãos favoráveis pode aumentar as chances de adoção de novas cultivares. Objetivouse selecionar genitores e populações segregantes promissoras para a extração de linhagens com escurecimento lento de grãos, associado à alta produtividade, tolerância ao acamamento e baixo tempo de cocção após o armazenamento; além de investigar a relação entre escurecimento de grãos e tempo de cocção após o armazenamento. Vinte populações segregantes (gerações $\mathrm{F}_{3}, \mathrm{~F}_{4}$ e $\mathrm{F}_{5}$ ) e seus genitores foram avaliados. $\mathrm{O}$ índice da soma de postos para caracteres combinados foi usado na seleção de populações superiores. Foram estimadas as correlações genéticas e fenotípicas entre o escurecimento e o tempo de cocção dos grãos após o armazenamento. Entre os genitores, a cultivar BRSMG Madrepérola foi a mais promissora para gerar linhagens com escurecimento de grãos. As populações superiores foram BRSMG Madrepérola x IPR Saracura, BRSMG Madrepérola x BRS Sublime, BRSMG Madrepérola x BRS Estilo e BRSMG Madrepérola x BRS Notável. Não foi detectada associação linear entre escurecimento de grãos e tempo de cocção de grãos após o armazenamento, indicando que o primeiro atributo não é indicador adequado para inferir sobre tempo de cocção.
\end{abstract}

PALAVRAS-CHAVE: Phaseolus vulgaris; qualidade de grão; índice de seleção.

with these traits are more suitable for mechanized harvest.

In addition, consumers and industry requirements have increased the demand for cultivars with a better seed quality. Among the traits associated with seed quality is seed-coat darkening, since darker colored seeds decrease the economic value of the product. Consumers relate bean seed-coat darkening

1. Manuscript received in Sep./2017 and accepted for publication in Mar./2018 (http://dx.doi.org/10.1590/1983-40632018v4849519).

2. Universidade Federal de Goiás, Escola de Agronomia, Goiânia, GO, Brasil.E-mails: eng.fernanda09@gmail.com, pgsantos@gmail.com.

3. Empresa Brasileira de Pesquisa Agropecuária (Embrapa Arroz e Feijão), Santo Antônio de Goiás, GO, Brasil.

E-mails: helton.pereira@embrapa.br, leonardo.melo@embrapa.br. 
to the aging process, which, for its part, lengthens the cooking time. Thus, efforts are directed to develop cultivars that have light color seeds and that maintain this light color for a longer time (Silva et al. 2008), as well as cultivars that exhibit an acceptable cooking time, even after a period of storage.

Genetic studies on slow seed-coat darkening are recent and show a wide genetic variability for the trait (Junk-Knievel et al. 2007). Its inheritance is controlled by one or few genes (Junk-Knievel et al. 2008, Silva et al. 2008, Elsadr et al. 2011, Araújo et al. 2012, Silva et al. 2014). Test lines and two cultivars (BRSMG Madrepérola and BRS Requinte) with slow seed-coat darkening have already been identified for the Carioca group (cream colored seeds with brown stripes), in Brazil (Faria et al. 2004, Silva et al. 2008, Araújo et al. 2012, Carneiro et al. 2012, Silva et al. 2014).

Despite the signs of a direct relationship between seed-coat darkening and longer seed cooking time (Coelho et al. 2008, Oliveira et al. 2011a and 2011b), such conclusions were based on evaluations of lines with normal seed-coat darkening over time. Thus, it is necessary to better understand this association in lines with slow seed-coat darkening.

In breeding programs, the genetic complexity of the most interesting traits hinders the selection of superior lines. Nevertheless, it is well known that various traits must be considered together during the selection process, and, for common bean, a simultaneous selection for agronomic traits and seed quality makes the success of new cultivars possible.

This study aimed to select promising parents and segregating populations for developing lines with slow seed-coat darkening, associated with a high grain yield, high lodging tolerance and short cooking time after storage, as well as investigate the relationship between seed-coat darkening and seed cooking time after storage.

\section{MATERIAL AND METHODS}

Biparental crosses were made between cultivars with slow seed-coat darkening (BRS Requinte and BRSMG Madrepérola) and ten other cultivars with normal seed-coat darkening, but with several superior agronomic traits (BRS Estilo, Pérola, BRS Cometa, BRS Pontal, BRSMG Majestoso, IAC Alvorada, IPR Saracura, IPR Siriri, BRS Sublime and BRS Notável).
The twenty obtained populations were evaluated in $\mathrm{F}_{3}, \mathrm{~F}_{4}$ and $\mathrm{F}_{5}$ generations, together with their parents, in Santo Antônio de Goiás (StA), Goiás state $\left(16^{\circ} 28^{\prime} 00^{\prime \prime} \mathrm{S}, 49^{\circ} 17^{\prime} 00^{\prime \prime} \mathrm{W}\right.$ and $823 \mathrm{~m}$ of altitude), and in Ponta Grossa (PtG), Paraná state (2505'42"S, 5009'43" $\mathrm{W}$ and $969 \mathrm{~m}$ of altitude), both in Brazil, in different crop seasons (winter, rainy and dry), in 2010 and 2011, namely: $\mathrm{F}_{3}$ in StA/ winter/2010, $\mathrm{F}_{4}$ in $\mathrm{PtG} /$ rainy/2010 and PtG/dry/2011, and $\mathrm{F}_{5}$ in StA/dry/2011 and StA/winter/2011.

The experimental design used in all the experiments was randomized complete blocks, with three replications. Each plot consisted of four 4-m length rows spaced at $0.45 \mathrm{~m}$. The cropping practices followed the recommendations for the crop (Melo 2009), except for the chemical control of diseases, which was not performed.

The traits evaluated were grain yield, lodging tolerance, seed-coat darkening and seed cooking time after storage. Grain yield was obtained from the two center rows of each plot and transformed into $\mathrm{kg} \mathrm{ha}^{-1}$. Lodging tolerance was evaluated by a scoring scale ranging from 1 to 9 , where 1 corresponds to a phenotype fully adapted to mechanized harvest and 9 to the phenotype unsuitable for mechanized harvest (Melo 2009). Yields were evaluated in four experiments (PtG/rainy/2010/ $\mathrm{F}_{4}$, PtG/dry/2011/ $\mathrm{F}_{4}$, $\mathrm{StA} / \mathrm{dry} / 2011 / \mathrm{F}_{5}$ and $\mathrm{StA} /$ winter $/ 2011 / \mathrm{F}_{5}$ ), whereas lodging tolerance was evaluated in the experiments $\mathrm{StA} / \mathrm{dry} / 2011 / \mathrm{F}_{5}$ and $\mathrm{StA} /$ winter $/ 2011 / \mathrm{F}_{5}$.

For evaluating seed-coat darkening, 40 individual plants were harvested per plot in the two side rows, for a total of 120 progenies of each treatment in each one of the experiments (StA/ winter $/ 2010 / \mathrm{F}_{3}$ and $\mathrm{PtG} / \mathrm{rainy} / 2010 / \mathrm{F}_{4}$ ). The seeds of each progeny were stored in transparent polyethylene packages under ambient environmental conditions (temperature of $24 / 28^{\circ} \mathrm{C}$ and humidity of $40 / 80 \%$ ), in Santo Antônio de Goiás. Seed-coat darkening was evaluated at 155 days after harvest, attributing scores from 1 to 5 , according to the scale proposed by Silva et al. (2008), where 1 is assigned to seeds with very light seed-coat color and 5 is assigned to seeds with very dark seed-coat color. The score of each plot was the mean evaluation score of the 40 progenies from each population, and the score of each treatment was obtained from the mean of the three replications.

For seed-cooking time evaluation, grain samples of each progeny were taken to obtain a 
composite sample (25 seeds per plot, in duplicate) of the plot from the same experiments evaluated for seed-coat darkening. The samples were evaluated at 190 days after storage, using a Mattson cooker (Carbonell et al. 2003). The time for the first 13 plunger rods to fall was considered the mean cooking time of each sample.

The data were subjected to variance analyses by experiment and to a joint variance analysis for all experiments, assuming the genetic treatments and environments as fixed effects. The treatment means were compared by the Scott-Knott test at $10 \%$ of probability. This significance level was used to reduce the probability of type II error on the genotypic discrimination, what is recommended when small differences among the treatments are expected (Zimmermann 2004). The experimental quality was evaluated by selective accuracy, according to the expression (Rezende \& Duarte 2007): Ac = $(1-1 / F)^{0.5}$, where $F$ is the value of the $F$ test for the genetic treatments (if $\mathrm{F}<1$, it was assumed $\mathrm{Ac}=0$ ).

To combine the information of all measured traits, the index proposed by Mulamba \& Mock (1978) was used, which transforms the phenotypic means into ranks, classifying the populations in relation to each one of the traits in an order that favors the aims of the selection. Different weights were attributed to each trait, according to their importance in the selection process: 1 for seed-cooking time; 2 for grain yield and lodging tolerance; and 8 for seedcoat darkening (main focus in this study).

Genetic $\left(\mathrm{r}_{\mathrm{G}}\right)$, phenotypic $\left(\mathrm{r}_{\mathrm{p}}\right)$ and environmental $\left(\mathrm{r}_{\mathrm{E}}\right)$ correlation between seed-coat darkening and seed-cooking time were estimated by covariance analyses (Ramalho et al. 2012), using the t-test to check the statistical significance of the estimates. Analyses were performed with the Genes software (Cruz 2013).

\section{RESULTS AND DISCUSSION}

The coefficients of variation were low for all the traits evaluated in all the experiments (Table 1), showing a good experimental quality, which can be confirmed by the estimates of selective accuracy with very high $(A c \geq 0.90)$ or high $(0.70 \leq A c<0.90)$ accuracy for all traits (Cargnelutti Filho \& Storck 2009).

Table 1. Summary of individual and joint variance analyses for seed-coat darkening (DAR), lodging tolerance (LT), seed-cooking time after storage (CTS) and grain yield (GY) of lines and populations ${ }^{1}$.

\begin{tabular}{|c|c|c|c|c|c|c|}
\hline \multirow{2}{*}{ Source of variation } & \multirow{2}{*}{$\mathrm{DF}^{2}$} & \multicolumn{3}{|c|}{ Mean square (MS) } & \multirow{2}{*}{$\mathrm{DF}$} & \multirow{2}{*}{$\begin{array}{l}\text { MS } \\
\text { GY }\end{array}$} \\
\hline & & DAR & LT & CTS & & \\
\hline Blocks/Environment (B/E) & 2 & 0.257 & 0.068 & 1.384 & 2 & 182,762 \\
\hline Environments (E) & 1 & $5.257^{*}$ & $20.672 *$ & $60.472 * *$ & 3 & $9,872,396^{* *}$ \\
\hline Treatments $(\mathrm{T})$ & 31 & $2.297 * *$ & $6.681 * *$ & $165.501 * *$ & 31 & $321,625 * *$ \\
\hline Populations $\left(\mathrm{T}_{0}\right)$ & 19 & $1.586^{* *}$ & $3.953 * *$ & $116.844 * *$ & 19 & $271,704 * *$ \\
\hline Populations $1\left(\mathrm{~T}_{1}\right)$ & 9 & $0.432 * *$ & $4.35^{* *}$ & 43.814 & 9 & $312,416^{* *}$ \\
\hline Populations $2\left(\mathrm{~T}_{2}\right)$ & 9 & $0.236^{* *}$ & $3.111 * *$ & 112.284 & 9 & $220,463^{*}$ \\
\hline $\mathrm{T}_{1}$ vs. $\mathrm{T}_{2}$ & 1 & $24.129 * *$ & $8.008 * *$ & $424.391 * *$ & 1 & 375,804 \\
\hline Parents $(\mathrm{P})$ & 11 & $3.331 * *$ & $11.629 * *$ & $261.424 * *$ & 11 & $372,677 * *$ \\
\hline $\mathrm{T}_{0}$ vs. $\mathrm{P}$ & 1 & $4.411 * *$ & $3.672 *$ & 3.672 & 1 & $693,532 * *$ \\
\hline $\mathrm{T} \times \mathrm{E}$ & 31 & $0.334 * *$ & $1.188^{*}$ & $157.15^{* *}$ & 93 & $241,278 * *$ \\
\hline $\mathrm{T}_{0} \times \mathrm{E}$ & 19 & 0.239 & 0.952 & $166.074 * *$ & 57 & $206,833 * *$ \\
\hline $\mathrm{T}_{1} \times \mathrm{E}$ & 9 & 0.177 & 0.824 & $105.814 *$ & 27 & 149,079 \\
\hline $\mathrm{T}_{2} \times \mathrm{E}$ & 9 & 0.285 & 1.178 & $181.329 *$ & 27 & $203,259 * *$ \\
\hline Contrast $^{3}$ & 1 & $0.393^{*}$ & 0.075 & $571.117^{* *}$ & 3 & $758,790 * *$ \\
\hline$P \times E$ & 11 & $0.513 * *$ & $1.586^{*}$ & 134.782 & 33 & $291,097 * *$ \\
\hline Pop: T x E & 1 & 0.141 & 1.292 & $233.653 * *$ & 3 & $347,712 *$ \\
\hline Residue & 124 & 0.077 & 0.67 & 32.157 & 248 & 99,398 \\
\hline Mean & - & 4.02 & 4.82 & 49.49 & - & 2,500 \\
\hline CV (\%) & - & 6.90 & 16.99 & 11.46 & - & 12.61 \\
\hline $\mathrm{Ac}^{4}$ & - & 0.98 & 0.95 & 0.90 & - & 0.83 \\
\hline
\end{tabular}


The individual variance analyses exhibited significant differences $(\mathrm{p}<0.01)$ among the genetic treatments for all traits evaluated, both for the parents and populations. Joint analyses confirmed these differences, just as they showed the differentiated performance of the parents and populations, in relation to the environments assessed, due to the genotype $\mathrm{x}$ environment interaction for all traits (Table 1). This interaction has been reported for seedcoat darkening (Junk-Knievel et al. 2007, Araújo et al. 2012), and possible causes are the sensitivity of genotypes to environmental variations, as well as differences in the harvest seasons and variations in light, temperature and moisture (Junk-Knievel et al. 2007). Similar results have been described for grain yield (Pereira et al. 2012), seed-cooking time (Perina et al. 2010, Ribeiro et al. 2013) and lodging tolerance (Mendes et al. 2009, Pereira et al. 2012).

Due to the constant need to develop new lines, the identification of superior parents allows a combination with other candidate parents for the formation of segregating populations that combine favorable phenotypes from both parents. Considering the four traits together, none of the evaluated parents united desirable phenotypes for all the traits, what is also reported in the literature (Mendes et al. 2009, Vale et al. 2015). Nevertheless, some parents stood out by performing well for most of the traits and by creating populations with desirable phenotypes, such as BRS Sublime, IPR Siriri, BRSMG Madrepérola and BRS Estilo (Table 2).

The segregating populations with less seedcoat darkening were: BRSMG Madrepérola $\mathrm{x}$ IAC Alvorada (3.13); BRSMG Madrepérola x BRS Sublime (3.17); BRSMG Madrepérola x IPR Saracura (3.23); BRSMG Madrepérola x IPR Siriri (3.23); and BRSMG Madrepérola x BRS Estilo (3.29) (Table 2). In this case, none of the populations had a performance similar to the best parent, what may be explained by the fact that the mean score of each population was obtained by the average of scores of each progeny. In addition, the allocation of the parents with slow seed-coat darkening in the same group did not allow the formation of segregating populations from two parents with this feature.

The population that had the best performance for lodging tolerance and similar performance to the best cultivars was BRS Requinte x BRS Sublime. The highest yields were obtained for BRSMG Madrepérola x IPR Saracura, BRSMG Madrepérola x
BRS Estilo and BRSMG Madrepérola $x$ BRS Pontal (Table 2). Thus, the comparative performance among these populations and the highest yielding parents (BRSMG Majestoso, BRS Estilo, Pérola, BRS Pontal and BRS Sublime) shows the possibility of selecting lines with higher grain yields.

For seed-cooking time after storage, the populations with lower mean values were BRS Requinte $x$ BRS Estilo (40.6 min), BRS Requinte $x$ IPR Saracura (41.6 min) and BRS Requinte x BRS 9435 Cometa (42.6 min) (Table 2).

In general, considering the means for each trait, populations with performance equal to that of the best cultivar checks were identified, indicating the high potential for developing superior lines. Moreto et al. (2007) showed that the selection of common bean lines considering only grain yield contributes to developing less upright plants, a feature that would hinder cropping practices. However, it has been shown that it is possible to develop plants combining upright architecture, high yield and type of seeds required for the consumer market (Mendes et al. 2009, Silva et al. 2009). Therefore, it is necessary that such traits be considered simultaneously in selection.

According to the selection index obtained from the four traits, the rank sum for the populations ranged from 94 to 301 (Table 2). A lower value indicates a more favorable combination, considering all the traits. Based on this index, the population BRSMG Madrepérola x IPR Saracura is noteworthy, since it unites desirable phenotypes for seed darkening and grain yield, though it has unfavorable performance for lodging tolerance. This may be explained by the importance placed on obtaining populations with slow seed-coat darkening. Alternatively, BRSMG Madrepérola x BRS Estilo showed good performances for all the traits together, and it is therefore the most recommended for obtaining superior lines. Moreover, although the parents IPR Saracura and BRS Sublime have a normal seed-coat darkening, in this study, they showed a good performance for this trait, indicating that the choice of parents among those that have normal darkening may have an effect on obtaining progenies with slow seed-coat darkening. Two other populations also selected for uniting favorable indexes, together with good phenotypes for yield, lodging and seed-coat darkening, were: BRSMG Madrepérola x BRS Sublime and BRSMG Madrepérola x BRS Notável. 
Table 2. Mean values ${ }^{1,2}$ for seed-coat darkening (DAR), grain yield (GY), lodging tolerance (LT) and seed-cooking time after storage (CTS) of parents and populations, estimates of Mulamba and Mock index $\left(\mathrm{I}_{\mathrm{MM}}\right)$ and ranks of genetic treatments for this index (R).

\begin{tabular}{|c|c|c|c|c|c|c|}
\hline Genetic treatment & DAR & GY & LT & CTS & $\mathrm{I}_{\mathrm{MM}}$ & $\mathrm{R}^{*}$ \\
\hline & \multicolumn{6}{|c|}{ Parents } \\
\hline BRSMG Madrepérola & $2.20 \mathrm{a}$ & $2,422 \mathrm{c}$ & $7.00 \mathrm{~d}$ & $55.41 \mathrm{c}$ & 119 & 1 \\
\hline BRS Sublime & $3.82 \mathrm{c}$ & $2,632 \mathrm{a}$ & $3.17 \mathrm{a}$ & $47.61 \mathrm{~b}$ & 128 & 2 \\
\hline IPR Siriri & $3.82 \mathrm{c}$ & $2,482 \mathrm{~b}$ & $3.17 \mathrm{a}$ & $45.29 \mathrm{~b}$ & 143 & 3 \\
\hline IPR Saracura & $3.99 \mathrm{c}$ & $2,217 \mathrm{c}$ & $5.83 \mathrm{c}$ & $35.57 \mathrm{a}$ & 197 & 5 \\
\hline IAC Alvorada & $4.14 \mathrm{~d}$ & $2,528 \mathrm{~b}$ & $4.17 \mathrm{~b}$ & $56.10 \mathrm{c}$ & 203 & 6 \\
\hline BRS Requinte & $4.39 \mathrm{e}$ & $2,476 \mathrm{~b}$ & $5.83 \mathrm{c}$ & $53.65 \mathrm{c}$ & 245 & 7 \\
\hline BRS Estilo & $4.45 \mathrm{e}$ & $2,773 \mathrm{a}$ & $3.83 \mathrm{~b}$ & $48.35 \mathrm{~b}$ & 194 & 4 \\
\hline BRS Pontal & $4.53 \mathrm{e}$ & $2,663 \mathrm{a}$ & $6.33 \mathrm{~d}$ & $55.95 \mathrm{c}$ & 266 & 9 \\
\hline Pérola & $4.70 \mathrm{f}$ & $2,677 \mathrm{a}$ & $5.33 \mathrm{c}$ & $47.49 \mathrm{~b}$ & 267 & 10 \\
\hline BRS 9435 Cometa & $4.82 \mathrm{f}$ & $2,398 \mathrm{c}$ & $2.67 \mathrm{a}$ & $53.70 \mathrm{c}$ & 308 & 11 \\
\hline BRSMG Majestoso & $4.83 \mathrm{f}$ & $2,859 \mathrm{a}$ & $4.33 \mathrm{~b}$ & $43.49 \mathrm{~b}$ & 261 & 8 \\
\hline \multirow[t]{2}{*}{ BRS Notável } & $4.95 \mathrm{f}$ & $2,537 \mathrm{~b}$ & $4.00 \mathrm{~b}$ & $57.93 \mathrm{c}$ & 318 & 12 \\
\hline & \multicolumn{6}{|c|}{ Populations } \\
\hline Madrepérola/Alvorada & $3.13 \mathrm{~b}$ & $2,268 \mathrm{c}$ & $5.67 \mathrm{c}$ & $49.32 \mathrm{c}$ & 117 & 6 \\
\hline Madrepérola/Sublime & $3.17 \mathrm{~b}$ & $2,500 \mathrm{~b}$ & $4.33 \mathrm{~b}$ & $54.02 \mathrm{c}$ & 99 & 2 \\
\hline Madrepérola/Siriri & $3.23 \mathrm{~b}$ & $2,397 \mathrm{c}$ & $4.33 \mathrm{~b}$ & $50.91 \mathrm{c}$ & 113 & 5 \\
\hline Madrepérola/Saracura & $3.23 \mathrm{~b}$ & $2,718 \mathrm{a}$ & $6.33 \mathrm{~d}$ & $50.78 \mathrm{c}$ & 94 & 1 \\
\hline Madrepérola/Estilo & $3.29 \mathrm{~b}$ & $2,669 \mathrm{a}$ & $4.83 \mathrm{~b}$ & $53.50 \mathrm{c}$ & 102 & 3 \\
\hline Madrepérola/Pérola & $3.60 \mathrm{c}$ & $2,573 \mathrm{~b}$ & $5.33 \mathrm{c}$ & $44.75 \mathrm{~b}$ & 106 & 4 \\
\hline Madrepérola/Notável & $3.67 \mathrm{c}$ & $2,468 \mathrm{~b}$ & $4.67 \mathrm{~b}$ & $45.78 \mathrm{~b}$ & 132 & 7 \\
\hline Madrepérola/Cometa & $3.69 \mathrm{c}$ & $2,259 \mathrm{c}$ & $4.67 \mathrm{~b}$ & $51.07 \mathrm{c}$ & 168 & 11 \\
\hline Madrepérola/Pontal & $3.76 \mathrm{c}$ & $2,661 \mathrm{a}$ & $6.83 \mathrm{~d}$ & $52.46 \mathrm{c}$ & 148 & 8 \\
\hline Madrepérola/Majestoso & $3.80 \mathrm{c}$ & $2,558 \mathrm{~b}$ & $4.83 \mathrm{~b}$ & $53.37 \mathrm{c}$ & 153 & 9 \\
\hline Requinte/Saracura & $4.01 \mathrm{~d}$ & $2,463 \mathrm{~b}$ & $5.50 \mathrm{c}$ & $41.58 \mathrm{a}$ & 185 & 12 \\
\hline Requinte/Siriri & $4.11 \mathrm{~d}$ & $2,551 \mathrm{~b}$ & $4.00 \mathrm{~b}$ & $48.26 \mathrm{~b}$ & 167 & 10 \\
\hline Requinte/Estilo & $4.21 \mathrm{~d}$ & $2,470 \mathrm{~b}$ & $4.50 \mathrm{~b}$ & $40.64 \mathrm{a}$ & 194 & 14 \\
\hline Requinte/Sublime & $4.23 \mathrm{~d}$ & $2,533 \mathrm{~b}$ & $3.50 \mathrm{a}$ & $45.87 \mathrm{~b}$ & 189 & 13 \\
\hline Requinte/Alvorada & $4.41 \mathrm{e}$ & $2,590 \mathrm{~b}$ & $4.83 \mathrm{~b}$ & $53.26 \mathrm{c}$ & 220 & 15 \\
\hline Requinte/Cometa & $4.46 \mathrm{e}$ & $2,368 \mathrm{c}$ & $4.33 \mathrm{~b}$ & $42.59 \mathrm{a}$ & 246 & 16 \\
\hline Requinte/Pérola & $4.47 \mathrm{e}$ & $2,281 \mathrm{c}$ & $5.33 \mathrm{c}$ & $52.82 \mathrm{c}$ & 285 & 17 \\
\hline Requinte/Majestoso & $4.54 \mathrm{e}$ & $2,284 \mathrm{c}$ & $5.00 \mathrm{~b}$ & $46.25 \mathrm{~b}$ & 286 & 18 \\
\hline Requinte/Notável & $4.55 \mathrm{e}$ & $2,201 \mathrm{c}$ & $4.00 \mathrm{~b}$ & $51.43 \mathrm{c}$ & 301 & 20 \\
\hline Requinte/Pontal & $4.56 \mathrm{e}$ & $2,539 \mathrm{~b}$ & $5.67 \mathrm{c}$ & $54.64 \mathrm{c}$ & 298 & 19 \\
\hline
\end{tabular}

${ }^{1}$ DAR: scores from 1 to 5 ; GY: $\mathrm{kg} \mathrm{ha}^{-1}$; LT: scores from 1 to 9 ; CTS: min. ${ }^{2}$ Mean values followed by the same letter in the column belong to the same group, according to the clustering criterion of Scott-Knott at $10 \%$ of significance.

From these results, segregating populations were able to be identified to obtain lines that combine slow seed-coat darkening and other favorable agronomic traits. Different studies have shown that the simultaneous selection of traits in common bean crop is effective. Mendes et al. (2009) used standardized variables ( $Z$ index) for the identification of superior segregating populations for grain yield, plant architecture and lodging. Lima et al. (2012) used this same index to choose superior lines with high yield, upright architecture and Carioca type seeds. From a simultaneous selection for agronomic traits and high concentrations of calcium and iron in the seeds, Ribeiro et al. (2013) also selected superior lines for most the traits.

Considering the performance of parents and populations, the phenotypic performances of the four lines mentioned are reflected in the superiority of the populations arising from these parents (BRSMG Madrepérola x IPR Saracura, BRSMG Madrepérola x BRS Sublime, BRSMG Madrepérola x BRS Estilo and BRSMG Madrepérola x BRS Notável). The parent BRS Sublime stood out by exhibiting favorable phenotypes for all the traits. The parent BRS Estilo is also noteworthy for exhibiting good mean values for all the traits, except for slow seed- 
coat darkening. However, it should be noted that this cultivar was effective in generating a superior segregating population for the traits together. Among the four best populations, two involved these parents in the crosses. In contrast with the per se performance of BRS Notável, for the traits of seed-coat darkening and cooking time after storage, this parent contributed favorably to the formation of superior populations for the traits in combination.

Although the BRSMG Madrepérola cultivar has some undesirable agronomic features, its superiority, in relation to lower seed-coat darkening, if compared to the BRS Requinte (Table 2), should be emphasized. This slow seed-coat darkening was also observed by Siqueira et al. (2014). Some studies have shown that the use of this line is effective in incorporating slow seed-coat darkening (Silva et al. 2008, Araújo et al. 2012, Silva et al. 2014). The populations that had the BRSMG Madrepérola as a parent showed to be superior, providing a significant reduction in seed-coat darkening for their progenies. Thus, the base population suitable for breeding should be constituted from at least one parent with good performance for the traits of interest (Cruz \& Regazzi 2001).

Estimates of genetic and phenotypic correlation between seed-coat darkening and cooking time after storage were not significant $(p>0.05)$ in any of the environments evaluated, neither for parents nor populations (Table 3 ). These results show that there was not a consistent linear association between the two traits. Thus, it may be inferred that the mean values of seed-coat darkening do not reflect the

Table 3. Estimates of genetic $\left(\mathrm{r}_{\mathrm{G}}\right)$, phenotypic $\left(\mathrm{r}_{\mathrm{p}}\right)$ and environmental $\left(\mathrm{r}_{\mathrm{E}}\right)$ correlation between seed-coat darkening and seed-cooking time after storage, considering all the genetic treatments, only parents or populations, evaluated in Santo Antônio de Goiás (StA) and Ponta Grossa (PtG), Brazil.

\begin{tabular}{llrrl}
\hline Location & Group & $\mathrm{r}_{\mathrm{G}}$ & $\mathrm{r}_{\mathrm{P}}$ & $\mathrm{r}_{\mathrm{E}}$ \\
\hline \multirow{4}{*}{ StA } & Treatments & 0.44 & 0.32 & 0.09 \\
& Parents & 0.41 & 0.36 & -0.16 \\
& Populations & 0.86 & 0.29 & 0.16 \\
\hline \multirow{3}{*}{$\mathrm{PtG}$} & Treatments & -0.08 & -0.02 & $0.52^{* *}$ \\
& Parents & -0.01 & 0.03 & 0.53 \\
& Populations & -0.21 & -0.11 & $0.55^{* *}$ \\
\hline \multirow{3}{*}{ Mean } & Treatments & -0.10 & -0.07 & 0.30 \\
& Parents & -0.01 & -0.01 & 0.07 \\
& Populations & -0.30 & -0.20 & 0.41 \\
\hline
\end{tabular}

** and *: significant at $1 \%$ and $5 \%$ of probability, respectively, by the t-test. performance of the lines for cooking time after storage. Hence, the genotype selection should be established in a particular way for each trait.

Siqueira et al. (2014) evaluated six Carioca bean genotypes over five months of storage, among them the BRS Requinte and BRSMG Madrepérola cultivars, and the CNFC 10467 line, all with slow seed-coat darkening. They found that, after the storage period, all the lines became darker and had a greater resistance to cooking; however, such events occurred at different intensities for each line, and they were not always correlated. Moreover, they found that the hardness of the cooked seeds had little to no correlation $(r \leq-0.44)$ to the luminance of the seeds, as well as little to no correlation to their chromaticity $\mathrm{a}(\mathrm{r} \leq 0.56)$ and $\mathrm{b}(\mathrm{r} \leq 0.50)$. Therefore, according to Siqueira et al. (2014), the color of the seed-coat in Carioca beans was not an appropriate correlated trait to predict cooking resistance or seed hardness over the storage period.

Different results were obtained by Araújo et al. (2012), who found positive and high estimates for phenotypic correlation $(\mathrm{r}=0.69 ; \mathrm{p}<0.05)$ between seed-coat darkening and seed-cooking time at 60 days after harvest. According to the authors, a lighter color is related to a faster seed cooking, even after a prolonged period of storage. Nevertheless, in evaluations made at 30 and 90 days after harvest, these estimates were not significant, what suggests that some interaction may have occurred. In that study, progenies from a single population were used, disregarding the effect of genetic background. In addition, significant effects for lines, environments and genotype $\mathrm{x}$ environment interaction for seedcooking time have frequently been reported (Perina et al. 2010, Ribeiro et al. 2013).

\section{CONCLUSIONS}

1. There is genetic variability among parents and among segregating populations, as well as the effect of genotype by environment interaction for seed-coat darkening;

2. The BRSMG Madrepérola cultivar has a great potential as a parent to develop segregating populations with slow seed-coat darkening;

3. The populations most recommended for developing lines with slow seed-coat darkening combined with high yield and lodging tolerance are those derived from crosses between the BRSMG Madrepérola 
and the parents IPR Saracura, BRS Sublime, BRS Estilo or BRS Notável;

4. There is no significant linear association between seed-coat darkening and seed cooking time after storage for the germplasm evaluated in this study.

\section{ACKNOWLEDGMENTS}

The authors thank the Embrapa Arroz e Feijão and Universidade Federal de Goiás, for funding and supporting this study; Coordenação de Aperfeiçoamento de Pessoal de Nível Superior (Capes), for granting a master's degree assistantship to the first author; and Conselho Nacional de Desenvolvimento Científico e Tecnológico (CNPq), for granting a Productivity Scholarship in Technological Development to the other authors.

\section{REFERENCES}

ARAÚJO, L. C. A.; RAMALHO, M. A. P.; ABREU, A. F. B. Estimates of genetic parameters of late seedcoat darkening of Carioca type dry beans. Ciência e Agrotecnologia, v. 36, n. 2, p. 156-162, 2012.

CARBOnELl, S. A. M.; CARVAlHO, C. R. L.; PEREIRA, V. R. Qualidade tecnológica de grãos de genótipos de feijoeiro cultivados em diferentes ambientes. Bragantia, v. 62, n. 3, p. 369-379, 2003.

CARGNELUTTI FILHO, A.; STORCK, L. Medidas do grau de precisão experimental em ensaios de competição de cultivares de milho. Pesquisa Agropecuária Brasileira, v. 44, n. 2, p. 111-117, 2009.

CARNEIRO, J. E. S. et al. BRSMG Madrepérola: common bean cultivar with late-darkening Carioca grain. Crop Breeding and Applied Biotechnology, v. 12, n. 4, p. 281284, 2012.

COELHO, C. M. M. et al. Capacidade de cocção de grãos de feijão em função do genótipo e da temperatura da água de hidratação. Ciência e Agrotecnologia, v. 32, n. 4, p. 1080-1086, 2008.

CRUZ, C. D. Genes: a software package for analysis in experimental statistics and quantitative genetics. Acta Scientiarum Agronomy, v. 35, n. 3, p. 271-276, 2013.

CRUZ, C. D.; REGAZZI, A. J. Modelos biométricos aplicados ao melhoramento genético. Viçosa: UFV, 2001.

ELSADR, H. T. et al. Characterization of seed coat postharvest darkening in common bean (Phaseolus vulgaris L.). Theoretical and Applied Genetics, v. 123, n. 8, p. 14671467, 2011.

FARIA, L. C. et al. 'BRS Requinte': new common bean Carioca cultivar with delayed grain darkness. Crop
Breeding and Applied Biotechnology, v. 4, n. 3, p. 366368, 2004.

JUNK-KNIEVEL, D. C.; VANDENBERG, A.; BETT, K. E. An accelerated post-harvest seed coat darkening protocol for Pinto beans grown across different environments. Crop Science, v. 47, n. 2, p. 694-702, 2007.

JUNK-KNIEVEL, D. C.; VANDENBERG, A.; BETT, K. E. Slow darkening in Pinto bean (Phaseolus vulgaris L.) seed coats is controlled by a single major. Crop Science, v. 48, n. 1, p. 189-193, 2008.

LIMA, L. K. et al. Implications of the progeny $x$ environment interaction in selection index involving characteristics of the common bean. Genetic and Molecular Research, v. 11, n. 4, p. 4093-4099, 2012.

MELO, L. C. Procedimentos para condução de ensaios de valor de cultivo e uso em feijoeiro-comum. Santo Antônio de Goiás: Embrapa Arroz e Feijão, 2009.

MENDES, F. F.; RAMALHO, M. A. P.; ABREU, A. F. B. Índice de seleção para escolha de populações segregantes de feijoeiro-comum. Pesquisa Agropecuária Brasileira, v. 44, n. 10, p. 1312-1318, 2009.

MORETO, A. L. et al. Estimação dos componentes da variância fenotípica em feijoeiro utilizando o método genealógico. Ciência e Agrotecnologia, v. 31, n. 4, p. 10351042, 2007.

MULAMBA, N. N.; MOCK, J. J. Improvement of yield potential of the Eto Blanco maize (Zea mays L.) population by breeding for plant traits. Egyptian Journal of Genetics and Cytology, v. 7, n. 1, p. 40-51, 1978.

OLIVEIRA, D. P. et al. Cooking time of grains of bean cultivars on the basis of the duration and storage conditions. Annual Report of the Bean Improvement Cooperative, v. 54, n. 1, p. 38-39, 2011 a.

OLIVEIRA, V. R. et al. Qualidade para o cozimento e composição nutricional de genótipos de feijão com e sem armazenamento sob refrigeração. Ciência Rural, v. 41, n. 5, p. 746-752, 2011 b.

PEREIRA, H. S. et al. Influência do ambiente em cultivares de feijoeiro-comum em Cerrado com baixa altitude. Bragantia, v. 71, n. 2, p. 165-172, 2012.

PERINA, E. F. et al. Avaliação de estabilidade e adaptabilidade de genótipos de feijoeiro (Phaseolus vulgaris $\mathrm{L}$.) baseada na análise multivariada da performance genotípica. Ciência e Agrotecnologia, v. 34, n. 2, p. 398406, 2010.

RAMALHO, M. A. P.; ABREU, A. F. B.; SANTOS, J. B.; NUNES, J. A. R. Aplicações da genética quantitativa no melhoramento de plantas autógamas. Lavras: UFLa, 2012. 
RESENDE, M. D. V.; DUARTE, J. B. Precisão e controle de qualidade em experimentos de avaliação de cultivares. Pesquisa Agropecuária Tropical, v. 37, n. 3, p. 182-194, 2007.

RIBEIRO, N. D. et al. Selection of common bean lines with high agronomic performance and high calcium and iron concentrations. Pesquisa Agropecuária Brasileira, v. 48, n. 10, p. 1368-1375, 2013.

SILVA, C. A.; ABREU, A. F. B.; RAMALHO, M. A. P. Associação entre arquitetura de planta e produtividade de grãos em progênies de feijoeiro de porte ereto e prostrado. Pesquisa Agropecuária Brasileira, v. 44, n. 12, p. 16471652, 2009.

SILVA, F. C. et al. Genetic control and estimation of genetic parameters for seed-coat darkening of Carioca beans. Genetics and Molecular Research, v. 13, n. 3, p. 6486-6496, 2014.

SILVA, G. S. et al. Genetic control of early grain darkening of Carioca common bean. Crop Breeding and Applied Biotechnology, v. 8, n. 4, p. 299-304, 2008.

SIQUEIRA, B. S. et al. Influence of storage on darkening and hardening of slow- and regular-darkening Carioca bean (Phaseolus vulgaris L.) genotypes. Journal of Agricultural Studies, v. 2, n. 2, p. 87-104, 2014.

VALE, N. M. et al. Escolha de genitores quanto à precocidade e produtividade de feijão tipo Carioca. Pesquisa Agropecuária Brasileira, v. 50, n. 2, p. 141-148, 2015.

ZIMMERMANN, F. J. P. Estatística aplicada à pesquisa agrícola. Santo Antônio de Goiás: Embrapa Arroz e Feijão, 2004. 